but that does not prevent marine action having previously taken a part in excavating them. Marine and meteoric denudations may have formed them at the first, but marine action built the bar across them, while marine and meteoric action is now filling them up, sometimes one and sometimes the other being the chief worker.

G. H. Kinahan.

\title{
MISCHIIAIVEOUS.
}

Discovery of a Coal Seam at Sandwell Park - A coal seam, two and a half feet thick, was lately struck in the Sandwell Park trial sinking, West Bromwich, at a depth of 380 yards, the seam "dipping" six inches per yard. Several mining engineers of great experience have visited the colliery, and pronounce the seam to be "brooch coal," in which case there can be little doubt that the thick coal measure is not far distant. The discovery has caused a good deal of excitement in the district, and an important advance in the value of the shares has. already been. established. Subsequently another seam known as the "Herringcoal" was reached, and the last reports state that they are still sinking in splendid Coal-ground.

OPITUARY.

\section{PROFESSOR PHILLIPS,}

Born 25th Dec. 1800. Died 24th Ápril, 1874.

The sad intelligence has just reached us of the loss of one of England's most eminent geologists, and, to very many amongst us, of a most dear and valued friend. Prof. Phillips's death was the result of an accident. On the 23rd April he had been dining at All Souls' College, and was returning, accompanied by the Principal of Jesus, when, in crossing the top of a staircase, his foot unhappily slipped, and he fell headlong down a flight of stone stairs. Paralysis and unconsciousness came on instantly, and about one o'clock on the 24th he expired. $\mathrm{He}$ was just 73 years of age.

Left an orphan at eight years of age to the care of his uncle William Smith, well known as "the father of English Geology," he was, as one may say, "to the hammer born." His connexion with the Yorkshire Philosophical Society dates back to 1826, and with the British Association from its establishment in 1831 ; indeed "he was the life and soul of its annual réunions." He presided over his favourite Geological Section last year at Bradford in his usual happy and delightful manner.

His connexion with Oxford dates back to 1853 . He has long outlived Buckland, De la Beche, Faraday, and Murchison, and has survived Sedgwick little more than a year. Few men have been more highly esteemed in life or will be more sincerely regretted in death than John Phillips.'

1 See Biographical Notice of Prof. Phillips (with a Portrait), Geol. Mag. 1870, Vol. VII. p. 301 . 